\title{
Modelling MNCs' Market Entry Order Strategy: Evidence from China
}

\author{
J.H. Qi ${ }^{a}, \underline{\text { Z.Y. Zhang }}{ }^{b}$ and H. Liu ${ }^{c}$ \\ ${ }^{a}$ School of Economics, Shandong University, China \\ ${ }^{b}$ School of Business \& Law, Edith Cowan University, Australia \\ ${ }^{c}$ School of Finance, Shandong University of Finance and Economics, China \\ Email: zhaoyong.zhang@ecu.edu.au (Zhang)
}

\begin{abstract}
There are a number of studies focusing on firms' export behavior and market entry decisions, but mostly applying the Net Present Value (NPV) Theory to the developed market economies and a few studies on the market entry order of multinational enterprises (MNEs) in the emerging economies (EM), especially on the largest trading country and the fastest growing emerging economy of China.
\end{abstract}

The purpose of this paper is to study the market entry order of the Chinese exporters and document the contribution of extensive margin during the internationalization process of Chinese MNEs by incorporating the unique institutional feature and matching the big data of China's Customs Database and Chinese Industrial Enterprise Database. In particular, we use the big matched data to screen exporting firms in a "new product-market combination" along with the extensive margin and at different product and ownership level from 2001 to 2006, and then examine whether a firm behaves as a pioneer or a follower when exporting a new combination and when a firm follows the pioneer to enter the market once they decide to become a follower in a new combination. To our knowledge this is among the first to study comprehensively the market entry order of Chinese MNEs in their internationalization process. This study implies three major contributions. First, it performs a comprehensive big data matching by industry, market, product line and ownership using China's Customs Database and Chinese Industrial Enterprise Database to study the market entry order of Chinese MNEs. This will allow us to better understand firms' export behaviors and market entry order and contribute to the existing literature. Then, this study examines not only Chinese MNEs' decision choice of being a pioneer or a follower, but also the timing of entry to the international market under different product categories and ownership. This advances our knowledge of how the Chinese MNEs internationalize and how to compare with MNEs from other countries. Finally, this study documents the dynamic contribution of extensive margin for the Chinese MNEs, and draws important policy implications on how and if China can sustain its rapid export growth.

The results show that firms' choice of being a pioneer or a follower in exporting each new productmarket portfolio is jointly determined by the firm-level and host-country-level characteristics, and that firms with larger scale, higher productivity, lower production costs, less fierce competition and smaller credit constraints are more likely to be pioneers. We also find that the timing when to follow is influenced by the pioneers' performance and product category. The results further confirm the existence of crowding out effect and spillover effect between pioneers and followers.

JEL Classification: $\quad$ F02; F23; G21

Keywords: $\quad$ Market entry order, extensive margin, new product-market portfolio (new portfolio), pioneers, followers 


\section{INTRODUCTION}

Firms' export behavior has been well documented but mostly using data sample from the developed countries. Since Melitz's (2003) seminal work on the theories of heterogeneous firms, there have been numerous applications and extensions examine firms' export behavior based on firm-level data in recent years. These studies investigate the reasons why some firms choose to export (Hallak and Sivadasan, 2011; Kulger and Verhoogen, 2012), the patterns they undertake when entering a new market (Antras, 2003; Helpman et al, 2004), the locations to where they export (Eaton et al, 2008; Schmeiser, 2012), and the quantity they decide to export. These applications and extensions have not only enriched the traditional trade theory, but also helped explain firms' export behaviors from different perspectives. However, most of the existing studies are based on the Net Present Value (NPV) Theory to explain firms' export behavior. It implies that firm will choose to export as long as its productivity and other heterogeneous factors can ensure the benefits exceed the costs. However, the NPV theory neglects four important facts with respect to export decision: the cost of entry is irreversible; the future revenue is uncertain; the timing of export can be delayed; and exporting firms interact by different competitive strategy (see Dixit and Pindyck, 1994; Albornoz et al, 2012; Wagner and Zahler, 2015). This casts doubt on the appropriateness of using the NPV theory in explaining firm's export decision.

There are a few studies on the market entry order of multinational enterprises (MNEs) in the emerging economies (EM), especially for the largest trading country and the fastest growing emerging economy of China. The general findings of these studies show that some firms would like to choose an export deferral strategy, even if they are capable of exporting their new product. They would prefer to imitate and/or start to export when other peer firms have done so. For instance, using a sample from Mexico, Iacovone and Javorcik (2010) report that there were 1,587 firms that were dedicated to new-product R\&D and willing to be the pioneers from 1995 to 2003, while 5,670 firms, or $72 \%$ of the firms chose to be the followers during the same period. By using a sample of 444 firm-product observations during the period in 1995-2006 from Chile, Wagner and Zahler (2015) report that there were 345 firms participated in the exports of 295 new products, and there were 136 pioneers and 308 followers. They also find evidence of spillover from a pioneer to other firms, and imitators tend to emerge relatively quickly once a pioneer becomes successful. It is generally found hard to explain the "self-decision" behavior of firms" export order under the NPV theoretical framework as firms need to weigh all the pros and cons of the first mover and follower, and decide not only what and where to export but also when to export. Moreover, studies have also found that the extensive margin of export plays an important role in sustainable growth of export (Bernard et al, 2009), while to defer their decision on export or to undertake a follower strategy in a new market will unquestionably restrain the growth of extensive margin (Hausmann and Rodrik, 2003). In this paper we intend to comprehend the study on the market entry order by providing new evidence from the process of internationalizing Chinese MNEs.

The purpose of this paper is to study the market entry order of the Chinese exporters and document the contribution of extensive margin during the internationalization process of Chinese MNEs by incorporating the unique institutional feature and using matching data from China's Customs Database and Chinese Industrial Enterprise Database. In particular, we use the big matched data to screen exporting firms in a "new product-market combination" along with the extensive margin and at different product and ownership level from 2001 to 2006, and then examine whether a firm behaves as a pioneer or a follower when exporting a new combination and when a firm follows the pioneer to enter the market once they decide to become a follower in a new combination. To our knowledge this is among the first to study comprehensively the market entry order of Chinese MNEs in their internationalization process. This study implies three major contributions:

- It performs a comprehensive big data matching by industry, market, product line and ownership using China's Customs Database and Chinese Industrial Enterprise Database to study the market entry order of Chinese MNEs. This will allow us to better understand firms' export behaviors and market entry order and contribute to the existing literature.

- This study examines not only Chinese MNEs' decision choice of being a pioneer or a follower, but also the timing of entry to the international market under different product categories and ownership. This advances our knowledge of how the Chinese MNEs internationalize and how to compare with MNEs from other countries.

- This study documents the dynamic contribution of extensive margin for the Chinese MNEs, and draws important policy implications on how and if China can sustain its rapid export growth. 
The remainder of the paper is structured as follows. Section 2 provides a brief literature review, followed by data description and stylized factors analysis in Section 3. Section 4 discusses the model, followed the empirical results in Section 5. The last section concludes the paper with policy implications.

\section{THEORETICAL FRAMEWORK}

The choice of market-entry time has been recognized as one of the major reasons for new product success or failure. First market entry rewards pioneers mostly in market share and the buildup of reputation and customer loyalty, though market pioneering is also a high-risk and expensive strategy (see Schmalensee, 1982; Johnson and Tellis, 2008). In particular, the first market entry advantages may include:

- utilize the time advantage to control supply and distribution channels, and gain access to scarce resources;

- build customer loyalty for new products and technological leadership, and exploit buyer switching costs to keep customers even if a follower enters the market to offer a technically superior product;

- make use of economies of scale, learning curve and patent protection to acquire the longterm cost advantage; and

- $\quad$ set up entry barriers to prevent the followers from entering the new market.

However, it is also recognized that pioneers have to undertake extra risks when pioneering a new and unfamiliar market. The main first-mover disadvantages include free-rider benefits to followers, market and technological uncertainties, unforeseen changes in technology or customer needs, and incumbent inertia, which results in the gradual updating of existing technology, rather than the adoption of new and improved technologies.

In contrast, the followers who chose to imitate and delay exporting can capitalize on pioneers' disadvantages, gain significant knowledge spillover from pioneers and save costs of discovering a new market. As a follower, firm can gain time to learn from the pioneers and to reduce the high entry costs and uncertainty in the new export market, which is conducive to improve the firm's success rate to entering a new market. It is also recognized that followers can gain time to observe the behavior of pioneers in the new market, which help them not only to acquire product information, but also obtain more effective market information, to eliminate the uncertainty of export (Wagner and Zahler, 2015). Moreover, the pioneer-follower spillover effects obtained by followers through "learning by doing" help improve their productivity and make their products more appealing and competitive in the market. This benefit is a kind of "dressed up" process for export (Naude et al., 2013).

Thus, firms need to balance the opportunities and benefits as a pioneer or follower and the associated risks and costs with each when making their market entry order decision. A potential follower must consider not only the marketing activities associated with first movers but also the increasing competition with other potential followers, while the pioneer has to bear the costs and risks of developing the new product and new market as well as the risk of imitation from the followers. The decision for firms to enter a new market should be timed to balance the risks of premature entry (entry too early) and the risk of missed opportunities (entry too late).

Most of the existing studies explain the choice of firms' market entry order from the perspective of micro firm-level and macro host-country-level characteristics. For a long time period, scale is largely synonymous with firm's competitiveness in the market. Compared to small-scale firms, large-scale firms with more resources have the advantage of scale economies in lower operation costs, and also a significant first-mover advantage in developing new export products and new market to effectively preventing followers from entering the market. Gaba et al. (2002) find evidence that large-scale firms will enter foreign markets earlier than small-scale firms by using 500 US firm data in China. However, Wagner and Zahler (2015) report a different finding that firms with large scale will not only have to bear the entry cost for new export but also undertake the selection cost of different products when facing multiple choices in export. In comparison with small-scale firms with a single product, the large-scale firms are more inclined to act as followers. 
In recent years, some studies use the heterogeneous productivity of firms to explain their market entry order. For example, Sheard (2014) found that followers can obtain the spillover effect from pioneers which is useful for followers to reduce the entry costs, but the sensitivity of the high productivity firms to the learning effects is lower than that of the low productivity firms. As a result, the second-mover advantage of high productivity firms is smaller than that of low productivity firms. Hence the high productivity firms are found to enter a new market more quickly and a large market earlier, but into a small market later than the low productivity firms.

There are studies that suggest firms' export experiences in terms of firm participation in international market will facilitate the export of new products into new markets. This is because the more previous export experience, the stronger the resistance of the firm in facing of uncertainty in new market (Gaba et al., 2002). Besides that, the experience in international market can also help firms to reduce the entry costs and improve the earnings of exporters. Therefore, it is believed that firms with rich export experience tend to act as pioneers.

\section{DATA DESCRIPTION}

In this study we use matched data obtained from China's Customs Database and Chinese Industrial Enterprise Database spanning from 2000 to 2006 to study the market entry order decision of the Chinese MNEs. There are several reasons for us to choose this sample period, and among others, data availability is one of the most important considerations. As in this study we need the matched data based on "product-market-firm" dimension from the perspective of extensive margin, we are constrained by data availability of both the Chinese Customs Database and the Chinese Industrial Enterprise Database. Although the former has the most updated data available till 2015, the Industrial Enterprise Database contains data available only from 1997 to 2011. Moreover, for the latter, the quality of data from 2007-2011 is very poor, especially for the period in 2007-2009. As most of the relevant existing studies also use data from 2000 to 2006, we therefore decide to choose this sample period in our study to keep consistency and also for easy comparison. We develop our dataset as follows:

- The first step is to match the two databases. We sort out 1,519,478 firm data from the Chinese Industrial Enterprises Database during the period from 2000 to 2006 as the panel data in accordance with the firm code. Then, we match the panel data with data from the Chinese Customs Database according to firms' name using the sequential recognition method. As a result, we obtain a comprehensive matched dataset consistent of the basic information of firms such as their assets and the export information such as product code. Finally we process the data and obtain the final dataset with 865,241 observations.

- The second step is to define the "new product-market combination". We define China's HS-6 product data exported to the rest of the world during our pre-sample period in 1997-2000 as the benchmark export products, and then derive the new dataset of China's exports to the rest of the world from 2001 to 2006 by matching the products against the benchmark.

The final step is to define the pioneer and follower. We classify firms as pioneers or followers according to their sequence of entry in a new product and a new market. A firm is defined as a pioneer if it starts exporting a new product to a new market in the new export product-market combination during the first year. We define a firm as a follower if it began exporting the new product to the new market in subsequent years. Eventually we identify 15,732 new export product-market combinations consistent of 3,166 products and 135 countries, and 16,995 firms including with 8,167 pioneers and 13537 followers in our sample. And the total number of observations is 56,466 for this study.

Table 1 presents the classification results of China's exports in the new export product-market combinations during the period in 2001-2006. As it can be seen in Table 1, the number of pioneers each year is less than the number of new export product-market combinations during the period in 2001-2005, indicating that some firms have been identified as pioneers in the different new combinations. For example, Beijing Zhuochen Livestock Husbandry Company is identified as a pioneer in exporting both the product code 20130 (fresh or chilled boneless beef) to Jordan and the product code 20422 (fresh or chilled lamb with bone) to Kuwait, which would be counted twice when calculating the total number of new product-market combinations. It is also noted that the number of new followers increased dramatically from 571 to 7,911 during the period 2002-2006. This is not only due to the increase in the number of new export product-market combinations, 
but also due to the pioneer-follower spillover effects which have attracted a large number of firms to follow in the new combinations.

Table 1. Classification of New Export Product-Market Combinations and Firms by Entry Order

\begin{tabular}{|c|c|c|c|c|c|c|c|}
\hline & & 2001 & 2002 & 2003 & 2004 & 2005 & 2006 \\
\hline & bers of New Combinations & 2412 & 3623 & 3593 & 3514 & 2590 & - \\
\hline \multirow{2}{*}{ Pioneer } & Numbers & 1552 & 2419 & 2520 & 2827 & 2445 & - \\
\hline & Additional Export Value（US Billion） & 84.69 & 293.05 & 409.60 & 450.82 & 317.53 & - \\
\hline \multirow{2}{*}{ Follower } & Numbers & - & 571 & 1744 & 3825 & 5418 & 7911 \\
\hline & Additional Export Value（US Billion） & - & 45.72 & 252.81 & 508.77 & 1268.50 & 2531.56 \\
\hline
\end{tabular}

Source: China's Customs Database and Chinese Industrial Enterprise Database and author's calculations.

We further decompose the new export product-market combinations at industry level according to the number of pioneers and follower firms, and report the results in Table 2. As it can be seen in Table 2, there are 16,995 firms that enter into exporting the new product combinations from 29 different industries, and the distribution of pioneers and follower firms is closely related to the type of industry. For instance, textile industry ranks 1 st in terms of percentage share and numbers of both pioneers and followers. The reason is that for the textile industry China has successfully maintained its comparative advantage and established the distribution channels in the foreign countries, and hence firms in this industry will face less uncertainties when enter into exporting their textile products to the world market. In addition, the relatively lower entry barrier and a large number of firms in the textile industry are the other possible reasons in explaining the large number of pioneers and followers. By contrast, the industry of petroleum processing, coking and nuclear fuel processing has the least number of pioneers and followers. This is because industries like this one belong to the basic resource industry in China and have high entry barrier for firms to enter. According to China's National Bureau of Statistics, there were only 2,064 firms in this industry in 2013, indicating a great market concentration. Given the high domestic demand for oil and oil products in China, firms in this industry are mostly domestic market oriented as a result of which there is a small number of pioneers and followers in this industry. These industry-specific differences also suggest that we need to take the industry fixed effect into account in our empirical study in order to control the impact of industry differences on firms' market entry order choice.

Once a firm has decided to be a follower in some new export product-market combinations, the next decision the firm has to make is when to follow the pioneer and to enter the market. They may follow the pioneers immediately, or several years later after the pioneers have survived in the new market. We draw the Kaplan-Meier survival curve in Figure 1 to illustrate the delay time performed by the followers. It can be seen in Figure 1 that the followers' survival curve shows a downward trend indicating the probability of waiting is decreasing with the increase of the delay time

\section{MODEL SPECIFICATION}

Table 2. Classification of Pioneers and Followers by Industry

\begin{tabular}{|c|c|c|c|c|}
\hline Industry Classification & $\begin{array}{c}\text { percentage } \\
(\%)\end{array}$ & Ranking & $\begin{array}{l}\text { Numbers of } \\
\text { Pioneers }\end{array}$ & $\begin{array}{c}\text { Numbers of } \\
\text { Followers }\end{array}$ \\
\hline $\begin{array}{l}\text { HS13 Agricultural and Sideline Products Processing } \\
\text { Industry }\end{array}$ & 4.03 & 10 & 320 & 574 \\
\hline HS14 Food Manufacturing & 2.27 & 16 & 212 & 300 \\
\hline HS15 Beverages Manufactured Goods & 0.57 & 28 & 38 & 65 \\
\hline HS17 Textile Industry & 10.95 & 1 & 976 & 1619 \\
\hline $\begin{array}{l}\text { HS18 Textile and Garment, Shoes, Cap Manufacturing } \\
\text { Industry }\end{array}$ & 3.45 & 13 & 303 & 400 \\
\hline $\begin{array}{l}\text { HS19 Leather, Fur, Feathers (Down) and Manufactured } \\
\text { Goods }\end{array}$ & 1.81 & 18 & 140 & 224 \\
\hline $\begin{array}{l}\text { HS20 Wood Processing and Wood, Bamboo, Rattan, } \\
\text { Palm, Grass }\end{array}$ & 2.19 & 17 & 185 & 322 \\
\hline HS21 Furniture Manufacturing Industry & 1.72 & 20 & 118 & 261 \\
\hline HS22 Paper and Paper Products Industry & 1.30 & 24 & 117 & 181 \\
\hline HS23 Printing and Recording Media Replication & 0.61 & 27 & 51 & 78 \\
\hline HS24 Porting Goods Manufacturing & 2.77 & 15 & 228 & 407 \\
\hline $\begin{array}{l}\text { HS25 Petroleum Processing, Coking and Nuclear Fuel } \\
\text { Processing }\end{array}$ & 0.14 & 29 & 12 & 15 \\
\hline $\begin{array}{l}\text { HS26 Chemical Raw Materials and Chemical } \\
\text { Manufacturing Industry }\end{array}$ & 7.91 & 2 & 775 & 1055 \\
\hline HS27 Pharmaceutical Manufacturing Industry & 1.77 & 19 & 194 & 226 \\
\hline HS28 Chemical Fiber Manufacturing Industry & 0.90 & 25 & 81 & 127 \\
\hline HS29 Rubber Products & 1.71 & 21 & 157 & 254 \\
\hline HS30 Plastic Products Industry & 4.01 & 11 & 332 & 537 \\
\hline HS31 Non Metallic Mineral Products Industry & 4.14 & 9 & 361 & 587 \\
\hline $\begin{array}{l}\text { HS32 Black Metal Smelting and Rolling Processing } \\
\text { Industry }\end{array}$ & 1.67 & 22 & 148 & 246 \\
\hline $\begin{array}{l}\text { HS } 33 \text { Non-Ferrous Metal Smelting and Rolling } \\
\text { Processing Industry }\end{array}$ & 1.61 & 23 & 137 & 229 \\
\hline HS34 Metal Manufacturing Industry & 5.67 & 6 & 445 & 800 \\
\hline HS35 General Equipment Manufacturing industry & 7.16 & 3 & 609 & 1038 \\
\hline HS36 Special Equipment Manufacturing Industry & 4.97 & 8 & 446 & 694 \\
\hline $\begin{array}{l}\text { HS } 37 \text { Transportation Equipment Manufacturing } \\
\text { Industry }\end{array}$ & 5.33 & 7 & 417 & 817 \\
\hline $\begin{array}{l}\text { HS39 Electrical Machinery and Equipment } \\
\text { Manufacturing Industry }\end{array}$ & 6.82 & 5 & 458 & 1075 \\
\hline $\begin{array}{l}\text { HS40 Communication Equipment, Computers and } \\
\text { other Electronic Equipment }\end{array}$ & 7.02 & 4 & 608 & 924 \\
\hline HS41 Instrumentation and Culture, Office Machinery & 3.68 & 12 & 402 & 413 \\
\hline HS42 Comprehensive Utilization of Waste Resources & 3.01 & 14 & 264 & 391 \\
\hline $\begin{array}{l}\text { HS } 43 \text { Metal Products, Machinery and Equipment } \\
\text { Repair Industry }\end{array}$ & 0.82 & 26 & 25 & 133 \\
\hline
\end{tabular}

Source: China's Customs Database and Chinese Industrial Enterprise Database and author's calculations 
We use the binary choice model to investigate the determinants of the probability that a firm chooses to be a pioneer in a new export product-market combinations. As discussed earlier, firms' decision on being a pioneer or a follower is determined by the expected profits of exporting, and the expected profits are related to firm-specific, industry-specific and host country-specific characteristics. Thus, the process of a firm's market entry order decision can be modelled as follows:

$$
\operatorname{Pr}\left(\text { Pioneer }_{\text {ipm }, t}=1\right)=X_{\text {ipm }, t-1} \beta+Z_{m, t-1} \delta+\mu_{t}+\mu_{z}+\mu_{r}+\varepsilon
$$

where $\operatorname{Pr}\left(\right.$ Pioneer $\left._{\text {ipm,t }}=1\right)$ is the probability that firm $i$ chooses to be a pioneer in a new export product-market combination for product $p$ in country $m$ at year $t ; X$ denotes the vector of firm-level variables; $Z$ is the vector of host-country variables; $\mu_{t}, \mu_{z}$ and $\mu_{r}$ are time, industry and region fixed effects, respectively, used to capture time-invariant, industry-specific and region-specific heterogeneity; and $\varepsilon$ is the random error.

The dependent variable Pioneer $_{i p m, t}$ is a dummy variable that take a value of one if firm $i$ is a pioneer in the new product-market pair for exporting at time $t$. It is coded zero if firm $i$ is a follower at time $t$. The explanatory variables include both firm characteristics and host country factors. The former includes firm size, productivity, firm experience, credit constraint market share, and production cost. For the host country factors, we include GDP growth rate and Population to proxy the host country's market potential and market size. Following Johnson and Tellis (2008) and Gaba et al. (2002), we also include a composite indicator to reflect a host country's overall macroeconomic risk (Country risk) for export. The larger the composite indicator, the greater the risk of the host country. All the variables are lagged by one year when we estimate the model to avoid endogeneity problem.

Once a firm has decided to be a follower in exporting the new products, the next question to ask is when to follow the pioneer to enter the market. In other words, the firm needs to decide if to follow immediately, or several years later after the pioneer has exported. This is essentially a decision on how to weight the risks of entry too quickly and the risks of entry too late and missed the opportunities. Its main assumption is that the hazard functions of all the individuals are a multiple of an unspecified baseline hazard function. Therefore, the baseline hazard function is an arbitrary and non-negative function in time.

\section{EMPIRICAL RESULTS}

We first estimate Eq. (1) to determine the factors affecting a firm's entry order decision as pioneer in a new export product-market combination, and then turn to the entry timing decisions of the followers. Table 3 presents the estimation results.

As it can be seen in Table 3, all the estimates have the expected sign and are statistically significant except for Age, suggesting that the variables concerned have significant effects on the entry order choice of firms in a new export product-market pair.

At the micro-firm level, the results show that Size has positive sign with similar effects on the probability of choosing to be a pioneer for both the full sample estimation and the differentiated products categories. The coefficient of Productivity is also found positive, confirming its positive impact on firms' market entry order decision and indicating that the high productivity firms are to

\begin{tabular}{|c|c|c|c|c|c|c|c|}
\hline \multirow{2}{*}{\multicolumn{2}{|c|}{ Variables }} & \multicolumn{2}{|c|}{ Full-sample } & \multicolumn{2}{|c|}{ Homogeneous products } & \multicolumn{2}{|c|}{ Differentiated products } \\
\hline & & Coefficient & $\begin{array}{c}\text { Marginal } \\
\text { effect }\end{array}$ & Coefficient & $\begin{array}{c}\text { Marginal } \\
\text { effect }\end{array}$ & Coefficient & $\begin{array}{c}\text { Marginal } \\
\text { effect }\end{array}$ \\
\hline & Size & $\begin{array}{c}0.043^{* * * * *} \\
(3.73)\end{array}$ & $\begin{array}{c}0.006^{* * * * *} \\
(3.73)\end{array}$ & $\begin{array}{c}0.041 * * * * \\
(1.94)\end{array}$ & $\begin{array}{c}0.005^{* * * * *} \\
(1.94)\end{array}$ & $\begin{array}{c}0.042 * * * \\
(3.02)\end{array}$ & $\begin{array}{c}0.005^{* * * * *} \\
(3.03)\end{array}$ \\
\hline & & $2.039 * * *$ & $0.260 * * *$ & $1.784^{* * * * *}$ & $0.236 * * *$ & $2.092 * * *$ & $0.259^{* * * * *}$ \\
\hline & Productivity & $(28.08)$ & $(27.83)$ & $(12.86)$ & $(12.90)$ & $(24.35)$ & (24.04) \\
\hline & Age & $\begin{array}{l}0.000 \\
(0.09)\end{array}$ & $\begin{array}{l}0.000 \\
(0.09)\end{array}$ & $\begin{array}{l}0.000 \\
(0.38)\end{array}$ & $\begin{array}{l}0.000 \\
(0.38)\end{array}$ & $\begin{array}{l}0.000 \\
(0.15)\end{array}$ & $\begin{array}{l}0.000 \\
(0.15)\end{array}$ \\
\hline \multirow{7}{*}{$\begin{array}{c}\text { Firm-level } \\
\text { Variables }\end{array}$} & & $0.014^{* * * * *}$ & $0.002^{* * * * * *}$ & $0.012^{* * * * *}$ & $0.002 * * * *$ & $0.016^{* * * * *}$ & 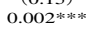 \\
\hline & Exports share & $(31.08)$ & $(32.47)$ & $(13.34)$ & $(13.84)$ & $(28.94)$ & $(30.36)$ \\
\hline & Credit constraint & $-0.133^{* * * * *}$ & -0.017 *水* & $-0.148 * * * *$ & 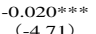 & $-0.128 * * * *$ & $-0.016^{* * * * *}$ \\
\hline & & $-7.585 * * * *$ & $-0.966 * * * *$ & $-9.903 * * *$ & $-1.309^{* * * *} *$ & $-7.038 * 2 * *$ & $\begin{array}{l}(-0.42) \\
-0.872^{2 * * * *}\end{array}$ \\
\hline & Market share & $(-39.60)$ & $(-40.71)$ & $(-23.65)$ & $(-23.54)$ & $(-32.99)$ & (34.15) \\
\hline & Production cost & $\begin{array}{c}-0.143 * * * * \\
(-10.37)\end{array}$ & $\begin{array}{c}-0.182 * * * * \\
(-10.44)\end{array}$ & $\begin{array}{c}-0.177 * * * * \\
(-6.78)\end{array}$ & $\begin{array}{c}-0.023 * * * * \\
(-6.86)\end{array}$ & $\begin{array}{c}-0.127 * * * * \\
(-7.78)\end{array}$ & $\begin{array}{c}-0.016 * \cdots * * \\
(-7.81)\end{array}$ \\
\hline & & 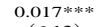 & 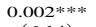 & 0.007 & 0.001 & $0.022^{* * * * *}$ & $0.003^{* * * * * k}$ \\
\hline \multirow{4}{*}{$\begin{array}{c}\text { Host- } \\
\text { country- } \\
\text { level } \\
\text { Variables }\end{array}$} & GDP growth & $(6.12)$ & $(6.14)$ & $(0.95)$ & $(0.95)$ & $(7.52)$ & $(7.55)$ \\
\hline & Population & $-0.077^{* * * * *}$ & $-0.010^{\text {***** }}$ & $-0.098 * * * *$ & $-0.013^{* * * * *}$ & $-0.076^{* * * * * k}$ & $-0.009 * 0 * *$ \\
\hline & & $(-8.45)$ & $(-8.47)$ & $(-5.82)$ & $(-5.85)$ & $(-6.89)$ & $(-6.91)$ \\
\hline & Country risk & $\begin{array}{c}-0.055 * * * \\
(-4.61)\end{array}$ & $\begin{array}{c}-0.007 \text { ***** } \\
(-4.62)\end{array}$ & $\begin{array}{l}-0.012 \\
(-0.47)\end{array}$ & $\begin{array}{l}-0.002 \\
(-0.47)\end{array}$ & $\begin{array}{c}-0.081 * \cdots * k \\
(-5.93)\end{array}$ & $\begin{array}{c}-0.010 \text { (1) } \\
(-5.94)\end{array}$ \\
\hline \multirow{2}{*}{\multicolumn{2}{|c|}{$\begin{array}{c}\text { Time FE } \\
\text { Industry FE }\end{array}$}} & \multirow{2}{*}{\multicolumn{2}{|c|}{ YES }} & \multirow{2}{*}{\multicolumn{2}{|c|}{$\begin{array}{l}\text { YES } \\
\text { YES }\end{array}$}} & & \\
\hline & & & & & & & \\
\hline & Region FE & \multicolumn{2}{|c|}{ YES } & \multicolumn{2}{|c|}{ YES } & \multicolumn{2}{|c|}{ YES } \\
\hline & Wald chi2 & \multicolumn{2}{|c|}{10947.37} & & \multirow{2}{*}{\multicolumn{2}{|c|}{$\begin{array}{c}8058.82 \\
0.42\end{array}$}} \\
\hline & & \multirow{2}{*}{\multicolumn{2}{|c|}{$\begin{array}{c}0.432 \\
-14456.36 \\
56466\end{array}$}} & \multirow{2}{*}{\multicolumn{2}{|c|}{$\begin{array}{c}0.422 \\
-4237.12\end{array}$}} & \multirow{2}{*}{\multicolumn{2}{|c|}{$\begin{array}{c}0.442 \\
-10096.25 \\
26361\end{array}$}} \\
\hline $\log _{1}$ & $\begin{array}{l}\text { seudolikelihood } \\
\text { N }\end{array}$ & & & & & & \\
\hline
\end{tabular}
enter a new market more quickly. As it can be seen in Table 4, the absolute magnitude of the coefficient for Productivity is greater than Firm Size. This finding lends support to the heterogeneous firm theory in 
explaining why more productive firms are likely to enter into exporting for a given entry cost. It is interesting to note that Export experience of a firm is a significant factor influencing firm's decision on being a pioneer, but not the age of the firm. Credit constraint is not often used in the existing studies in explaining the entry order choice of an exporter, but it is recognized that the accessibility of financing can have direct impact on firm's market entry order decision. Our results show that this variable has a significant negative effect on firms' choice decision. The coefficient of Market share is negative, which means the more fierce competition the firms facing, the more the likely for firms to choose to be pioneers. At the macro-country level, the results suggest that the economic growth rate of the host country can stimulate the enthusiasm of firms to be pioneers. But the coefficient of population is negative, suggesting there exists the crowing-out effect, i.e., there exists a negative relationship between the size of the potential markets and the first mover advantage. Moreover, the higher the host country's risk, the lower the probability of firms choosing to be pioneers. The high country risk means high uncertainty, which implies in this case the second-mover advantage as followers will be large. We have also conducted the robustness test by using both homogenous and differentiated products, and found all the signs of the estimates remain the same, but there are some differences in their marginal effect and significance.

\section{CONCLUSION}

By matching the big data of China's Customs Database and Chinese Industrial Enterprise Database, we examine the market entry order strategy of the Chinese exporters in the process of internationalization. The results show that firms' choice of being a pioneer or a follower in exporting each new product-market combination is jointly determined by the firm-level and host-country-level characteristics, and that firms with larger scale, higher productivity, lower production costs, less fierce competition and smaller credit constraints are more likely to be pioneers. We also find that the timing when to follow is influenced by the pioneers' performance and product category. The results further confirm the existence of crowding out effect and spillover effect between pioneers and followers.

\section{REFERENCES}

Albornoz, F., F. Hector., C. Pardo., G. Corcos and E. Ornelas (2012). "Sequential Exporting", Journal of International Economics, 88(1), 17-31.

Antras, P. (2003). "Firms, Contracts and Trade Structure”, Quarterly Journal of Economics, 11, pp. $1375-1418$.

Dixit, A. K and R.S. Pindyck (1994). Investment under Uncertainty. Princeton University Press.

Eaton, J., E. Marcela., M. Kuglery and J. Tybout (2008). "Export Dynamics in Colombia: Transactions Level Evidence", Borradores de Economia, Banco de la Republica de Colombia 522.

Gaba, V., Y. Pan and G. Ungson (2002). "Timing of Entry in International Market: An Empirical Study of U.S. Fortune 500 Firms in China", Journal of International Business Studies, 33(1), 39-55.

Hallak, J.C and J. Sivadasan (2013). "Product and Process Productivity: Implications for Quality Choice and Conditional Exporter Premia”, Journal of International Economics, 91(1), 53-67.

Helpman, E., Melitz M.J. and S.R. Yeaple (2004). "Export versus FDI with Heterogeneous Firms", American Economic Review, 94(1), 300-316.

Hausmann, R., and D. Rodrik (2003). "Economic Development as Self-Discovery", Journal of Development Economics, 72, 603-633.

Iacovone, L. and B. Javorcik (2010). "Multi-product Exporters: Product Churning, Uncertainty and Export Discoveries", Economic Journal, 120, 481-499.

Johnson, J. and G. J. Tellis (2008). "Drivers of Success for Market Entry into China and India", Journal of Marketing, 72(3), 1-13.

Melitz, M. (2003). "The Impact of Trade on Intra-Industry Reallocations and Aggregate Industry Productivity", Econometrica, 71(6), 1695-1725.

Naude, W., T. Gries and N.Bilkic (2013). "Firm-level Heterogeneity and the Decision to Export: A Real Option Approach”, IZA DP, No. 7346.

Schmalensee, R. (1982). "Product Differentiation Advantages of Pioneering Brands", American Economic Review, 72, 349-365.

Schmeiser, K.N. (2012). "Learning to Export: Export Growth and The Destination Decision of Firms", Journal of International Economics, 87, 89-97.

Sheard, N. (2014). "Learning to Export and the Timing of Entry to Export Markets", Review of International Economics, 22(3), 536-560.

Wagner, R and A. Zahler (2014). "New Exports from Emerging Markets: Do Followers Benefit from Pioneers?" Journal of Development Economics, forthcoming, 2014. 